\title{
The physiological role of Homer2a and its novel short isoform, Homer2e, in NMDA receptor-mediated apoptosis in cerebellar granule cells
}

\author{
Teiichi Furuichi ${ }^{1,2,3^{*}}$, Yuko Muto ${ }^{1}$, Tetsushi Sadakata ${ }^{1,2,4}$, Yumi Sato $^{1,5}$, Kanehiro Hayashi $^{1,2,6}$, \\ Yoko Shiraishi-Yamaguchi $i^{1,7}$ and Yo Shinoda ${ }^{1,2,8^{*}}$ (i)
}

\begin{abstract}
Homer is a postsynaptic scaffold protein, which has long and short isoforms. The long form of Homer consists of an $\mathrm{N}$-terminal target-binding domain and a C-terminal multimerization domain, linking multiple proteins within a complex. The short form of Homer only has the $\mathrm{N}$-terminal domain and likely acts as a dominant negative regulator. Homer2a, one of the long form isoforms of the Homer family, expresses with a transient peak in the early postnatal stage of mouse cerebellar granule cells (CGCs); however, the functions of Homer2a in CGCs are not fully understood yet. In this study, we investigated the physiological roles of Homer2a in CGCs using recombinant adenovirus vectors. Overexpression of the Homer2a N-terminal domain construct, which was made structurally reminiscent with Homer1a, altered NMDAR1 localization, decreased NMDA currents, and promoted the survival of CGCs. These results suggest that the Homer2a N-terminal domain acts as a dominant negative protein to attenuate NMDAR-mediated excitotoxicity. Moreover, we identified a novel short form N-terminal domain-containing Homer2, named Homer2e, which was induced by apoptotic stimulation such as ischemic brain injury. Our study suggests that the long and short forms of Homer2 are involved in apoptosis of CGCs.
\end{abstract}

Keywords: Homer2, Cerebellar granule cell, NMDAR, Excitotoxicity

\section{Introduction}

Homer proteins are scaffold proteins that predominantly exist in the postsynaptic density (PSD) of neurons and tether a variety of target proteins within the PSDs, including the group I metabotropic glutamate receptor $1 \alpha / 5$ (mGluR1 $\alpha / 5)$, inositol 1,4,5-trisphosphate receptor $\left(\mathrm{IP}_{3} \mathrm{R}\right)$, and Shank, a scaffold protein for the N-methyl-Daspartate receptor (NMDAR) complex [1-4]. There are three distinct genes in the Homer family, Homer1/vesl-1,

*Correspondence: tfuruichi@rs.tus.ac.jp; yshinoda-ns@umin.net

${ }^{1}$ Laboratory for Molecular Neurogenesis, RIKEN Brain Science Institute, Wako, Saitama 351-0198, Japan

Full list of author information is available at the end of the article
Homer2/Cupidin/vesl-2, and Homer3, and they are classified into two major forms, long and short $[5,6]$. Long Homers, such as Homer $1 \mathrm{~b} / \mathrm{c} / \mathrm{d}, 2 \mathrm{a} / \mathrm{b}$, and $3 \mathrm{a} / \mathrm{b}$, consist of two main domains, the $\mathrm{N}$-terminal enabled/vasodilator-stimulated phosphoprotein homology 1 (EVH-1) domain for the target binding and the C-terminal coiledcoil domain for the self-multimerization [7]. However, the short Homer, such as Homerla, which has been reported as an immediate-early gene induced by electroconvulsive seizure in an activity-dependent manner [8], only has the $\mathrm{N}$-terminal target-binding domain. Thus, Homer 1a is thought to act as a natural dominant negative regulator by competing with long Homer proteins that form Homer-target protein multimers via the C-terminal original author(s) and the source, provide a link to the Creative Commons licence, and indicate if changes were made. The images or other third party material in this article are included in the article's Creative Commons licence, unless indicated otherwise in a credit line to the material. If material is not included in the article's Creative Commons licence and your intended use is not permitted by statutory regulation or exceeds the permitted use, you will need to obtain permission directly from the copyright holder. To view a copy of this licence, visit http://creativecommons.org/licenses/by/4.0/. The Creative Commons Public Domain Dedication waiver (http://creativeco mmons.org/publicdomain/zero/1.0/) applies to the data made available in this article, unless otherwise stated in a credit line to the data. 
domain $[9,10]$. In addition, Homerla is known to promote cell protection from apoptosis [11-13].

We have reported that Homer2a (also known as Cupidin), a long Homer isoform, has an expression pattern that peaks around postnatal day 7 during mouse cerebellar development [14] and is highly expressed in cerebellar granule cells (CGCs) [15]. In the postnatal stage with high Homer2a expression, a significant apoptotic event of CGCs is observed [16]. Additionally, the development and survival of CGCs is associated with glutamatergic activity via NMDAR [17]. It has also been reported that glutamate stimulation leads to the postsynaptic targeting of Homer2a and its declustering in CGCs [18]. Therefore, Homer2a may be associated with developmental events of CGCs including apoptosis, however, its physiological role has not been fully elucidated.

In this study, we investigated the physiological role of Homer2a and found its novel short isoform, Homer2e. We analyzed the effects of Homer2a on the clustering of NMDAR, and on NMDA currents and NMDA-induced apoptosis in CGCs. We also described the ischemia-associated induction of the novel alternative splicing Homer2 isoform, Homer2e, in CGCs.

\section{Materials and methods}

Cerebellar primary culture and oxygen-glucose deprivation (OGD)

Primary dissociated CGCs were prepared from fetal ICR mice (Nihon SLC, Hamamatsu, Japan) as described previously [19]. Briefly, cerebella from 18-day-old embryos were trypsinized with $1 \%$ trypsin (Sigma-Aldrich, St. Louis, MO, USA) and 500 units $/ \mathrm{mL}$ DNase I (SigmaAldrich) for $13 \mathrm{~min}$ at $37^{\circ} \mathrm{C}$ and were further triturated by repeated passage through a fine-tipped pipette in $\mathrm{Ca}^{2+}$-free Hank's balanced salt solution (HBSS; SigmaAldrich) containing 500 units/mL DNase I and $12 \mathrm{mM}$ $\mathrm{MgSO}_{4}$. Dispersed cells were plated at a density of $35 \times 10^{4}$ cells $/ \mathrm{cm}^{2}$ on poly-L-lysine-coated glass cover slips (Matsunami, Osaka, Japan), and then cultured in serum-free Eagle's medium supplemented with $1 \mathrm{mg} /$ $\mathrm{mL}$ bovine serum albumin, $10 \mu \mathrm{g} / \mathrm{mL}$ bovine insulin, $0.1 \mathrm{nM}$ l-thyroxine, $0.1 \mathrm{mg} / \mathrm{mL}$ human transferrin, $1 \mu \mathrm{g} /$ $\mathrm{mL}$ aprotinin (all from Sigma-Aldrich), $30 \mathrm{nM}$ sodium selenite (Merck, Darmstardt, Germany), 0.25\% glucose (Nacalai Tesque, Kyoto, Japan), 2 mM glutamine (Nacalai Tesque), $100 \mu \mathrm{g} / \mathrm{mL}$ streptomycin (Meiji Seika, Tokyo, Japan), and $100 \mathrm{U} / \mathrm{mL}$ penicillin (Banyu Pharmaceutical, Tokyo, Japan). The cultures were maintained at $37^{\circ} \mathrm{C}$ in a humidified incubator with $5 \% \mathrm{CO}_{2}$, and half the volume of the culture medium was replaced with fresh medium once a week. The cultures were used at 12-15 days in vitro (DIV). Oxygen-glucose deprivation experiment was carried out using AnaeroPack (MGC, Tokyo, Japan) according to the manufactures' instructions with Eagle's medium in the absence of glucose and incubated the cells for $90 \mathrm{~min}$ at $37{ }^{\circ} \mathrm{C}$ in a humidified incubator with $5 \%$ $\mathrm{CO}_{2}$.

\section{Generation and infection of adenoviruses expressing EGFP-Homer2a constructs}

The enhanced green fluorescent protein (EGFP)-coding region of pEGFP-C1 (Clontech, Cambridge, UK) was fused in frame to the Homer2a N-terminus or to mutants to generate EGFP-fused Homer2a constructs. Replication-deficient adenoviruses were generated with the COS-TPC method as described previously [20]. Briefly, the EGFP-tagged full-length $(\mathrm{H} 2 \mathrm{a}-\mathrm{F}), \mathrm{C}$-terminal $(\mathrm{H} 2 \mathrm{a}-$ $\mathrm{C})$, and $\mathrm{N}$-terminal domain of Homer2a $(\mathrm{H} 2 \mathrm{a}-\mathrm{N})$ were cloned into the SwaI site of the pAxCAwt cosmid cassette (Takara, Tokyo, Japan). The recombinant adenoviruses (AdVs) were generated by homologous recombination between an EcoT22I-digested Ad5-dlx DNA-terminal protein complex and recombinant cosmid vectors in HEK293 cells. The generated AdVs were propagated in HEK293 cells. The AdVs were concentrated and purified by double cesium chloride gradient centrifugation and the titers of AdVs were measured by the $50 \%$ tissue culture infectious dose method [21]. Cultured CGCs at 12 DIV were exposed to AdVs at a multiplicity of infection $=30$. Infected CGCs were analyzed $48 \mathrm{~h}$ after the infection (14 DIV).

\section{Immunocytochemistry}

Immunocytochemistry was performed as described previously with minor modifications [22]. Briefly, cells were fixed with $4 \%$ paraformaldehyde in $0.1 \mathrm{M}$ phosphate buffer, permeabilized in methanol for $30 \mathrm{~min}$ at $-30{ }^{\circ} \mathrm{C}$, preincubated with 5\% normal donkey serum in PBS for $1 \mathrm{~h}$, and then incubated with the primary antibodies, rabbit anti-Homer2a antibody [14] or mouse anti-NMDA receptor 1 (NR1) antibody (BD Transduction Laboratories, Lexington, $\mathrm{KY}, \mathrm{USA}$ ), for $16 \mathrm{~h}$ at $4{ }^{\circ} \mathrm{C}$. After washing with PBS, the samples were incubated with Alexa-conjugated secondary antibodies (Thermo Fisher Scientific, Waltham, MA, USA). Coverslips were mounted in Vectashield (Vector Laboratories, Burlingame, CA, USA) mounting medium. Immunofluorescence was observed using a Meta-510 confocal laser microscope (Zeiss, Oberkochen, Germany).

\section{Western blotting}

Western blotting was performed as described previously with minor modifications [23]. Total cell lysates prepared from CGC cultures were boiled in SDS-PAGE sample buffer. Samples were separated by SDS-PAGE gels and blotted onto a polyvinylidene difluoride membranes. 
Proteins on the membranes were immunodetected with rabbit anti-Homer2a, rabbit anti-pan Homer [15]. The immunoblots were incubated with horseradish peroxidase-conjugated secondary antibodies (KPL, Gaithersburg, MD, USA) and developed with ECL reagents (Amersham, Buckinghamshire, UK). The chemiluminescence was imaged by a LAS-3000 imaging system (Fujifilm, Tokyo, Japan). The band intensity was quantified with Image J (National Institutes of Health).

\section{Electrophysiology}

Whole-cell patch clamp recordings were obtained using a partly modified previously reported method [24]. AdVinfected CGCs on glass coverslips at 14 DIV (2 days after infection at 12 DIV) were transferred into the experimental chamber and superfused with modified Krebs-Ringer solution (mM): $145 \mathrm{NaCl}, 5 \mathrm{KCl}, 2 \mathrm{CaCl}_{2}, 10$ glucose, 10 HEPES, 0.01 glycine (pH 7.4 with $\mathrm{NaOH}$ ). Tetrodotoxin $(1 \mu \mathrm{M})$, bicuculline $(10 \mu \mathrm{M})$, and NBQX $(10 \mu \mathrm{M})$ were added to block action potential, GABAergic transmission, and non-NMDAR-mediated glutamatergic transmission, respectively. NMDA $(50 \mu \mathrm{M})$ and AP5 $(50 \mu \mathrm{M})$ were applied to elicit and block the NMDA current, respectively. All agonists and antagonists were purchased from Tocris (Tokyo, Japan). The experimental chamber, consisting of an acrylic frame with a glass bottom, was mounted on the stage of an inverted Eclipse TE2000-U phase contrast microscope (Nikon, Tokyo, Japan). Patch pipettes were made from glass capillaries (Clark Electromedical Instruments, Pangbourne, UK) using a P-97 horizontal puller (Sutter Instrument, Novato, CA, USA). The pipette had a direct current resistance of 4-7 $\Omega$ when it was filled with the following solution (mM): $140 \mathrm{D}$-glucuronate, $7 \mathrm{CsCl}, 155 \mathrm{CsOH}, 5$ EGTA, and 10 HEPES ( $\mathrm{pH} 7.2$ with $\mathrm{CsOH}$ ). The pipette was connected to patch clamp amplifier AXOPATCH 200B (Molecular Devices, San Jose, CA, USA) and filtered with a $1 \mathrm{kHz}$ Bessel lowpass filter.

\section{Cell survival assays}

The MTT assay was performed using MTT Kit I (Boehringer Mannheim, Mannheim, Germany) according to the manufacturer's instructions. Briefly, $10 \mu \mathrm{L}$ of the $5 \mathrm{mg} / \mathrm{mL}$ MTT labeling reagent was added to 100 $\mu \mathrm{L}$ of neuronal cultures in each well of 96-well culture plates, and the plates were incubated for $4 \mathrm{~h}$ at $37^{\circ} \mathrm{C}$ in a humidified incubator with $5 \% \mathrm{CO}_{2}$. Then, $100 \mu \mathrm{L}$ of the solubilizing solution was added to each well and further incubated overnight. Absorbance of the solubilized samples was measured at $570 \mathrm{~nm}$ and $700 \mathrm{~nm}$ (reference wavelength). The extent of MTT conversion in cells was expressed as a percentage of the control.

\section{Preparation of brain ischemia samples}

Transient global cerebral ischemia was induced using the bilateral occlusion of the common carotid arteries technique as previously described [25]. ICR mice at P56 were anesthetized and an incision was made in the ventral neck to expose the common carotid arteries. Brain ischemia was induced by bilateral occlusion of the common carotid arteries using aneurysm clips for $20 \mathrm{~min}$. At the end of each occlusion, the aneurism clips were removed, and the arteries were visually inspected for reperfusion. The incision was then closed with sutures.

\section{Nested PCR, molecular cloning, and RT-PCR of Homer2 isoforms}

The Homer2 isoforms were cloned by the nested PCR method using a mouse brain cDNA library and the following primers: the outer primer set, $5^{\prime}$ primer, Homer2a-5'-exon2-fw (5'-TCACCAGGAACAGCT ATCGG-3' ${ }^{\prime}$, corresponding to exon 2 of Homer $2 a$ ), and $3^{\prime}$ primer, Homer2a-3'-UTR-rev (5'-TCTGGAGAC AGACAGATCGC- $3^{\prime}$, corresponding to the $3^{\prime}$ untranslated region of Homer $2 a$ ), and the inner primer set, $5^{\prime}$ primer, Homer2a-5'-exon3-fw (5'-CGGTTTGGGATT CTCCTCCG-3', corresponding to exon3 of Homer $2 a)$, and $3^{\prime}$ primer, Homer2a-3'-exon9-rev (5'-TTTGAT TGTCTCTTTCGGCC-3', corresponding to exon9 of Homer $2 a$ ). Amplified DNA fragments were cloned into the pCR4-TOPO vector (Thermo Fisher Scientific) and sequenced. For RT-PCR, the TRIzol Reagent (Thermo Fisher Scientific) was used to prepare total RNA from cerebella of either normal or ischemia-induced mice (ICR at P56) and from CGC cultures that were untreated or subjected to oxygen and glucose deprivation for $60 \mathrm{~min}$. RNA samples were digested with RQ1 RNase-free DNase (Promega, Madison, WI, USA) for $30 \mathrm{~min}$ at $37{ }^{\circ} \mathrm{C}$. The resulting DNA-free RNAs were used to synthesize cDNAs using SuperScript II reverse transcriptase (Thermo Fisher Scientific) and oligo dT. PCR of the cDNAs was performed with an ExTaq polymerase kit (Takara) with specific primers bridging between exon 4 and exon 6 of Homer $2 a$. The PCR products were separated on $2 \%$ agarose gel and visualized using a UV transilluminator (Bio-Rad, Tokyo, Japan) after staining with ethidium bromide.

\section{Statistical analysis}

Data are presented as the mean \pm SEM. Comparisons of multiple data were statistically evaluated by one-way analysis of variance (ANOVA) and post hoc Bonferroni test. 


\section{Results}

Overexpression of exogenous Homer2a in CGCs

To clarify the function of Homer2a in CGCs, four recombinant $\mathrm{AdV}$ vectors were constructed (Fig. 1A): AdV carrying EGFP only, and three AdV constructs consisting of EGFP fused to full length (H2a-F), C-terminal (containing residues $112-343$; H2a-C) or N-terminal (containing residues 1-111; H2a-N) Homer2a, which structurally resemble a short form of Homer, like Homer1a.

We first confirmed that all the Homer2a proteins were overexpressed in CGCs by Western blotting (Fig. 1B). Cultured CGCs were infected with AdVs at 12 DIV and were analyzed $48 \mathrm{~h}$ after infection. The anti-Homer2a antibody, which binds to the C-terminus of Homer2a, immunodetected $\mathrm{H} 2 \mathrm{a}-\mathrm{F}$ and $\mathrm{H} 2 \mathrm{a}-\mathrm{C}$ but not the $\mathrm{H} 2 \mathrm{a}-\mathrm{N}$,

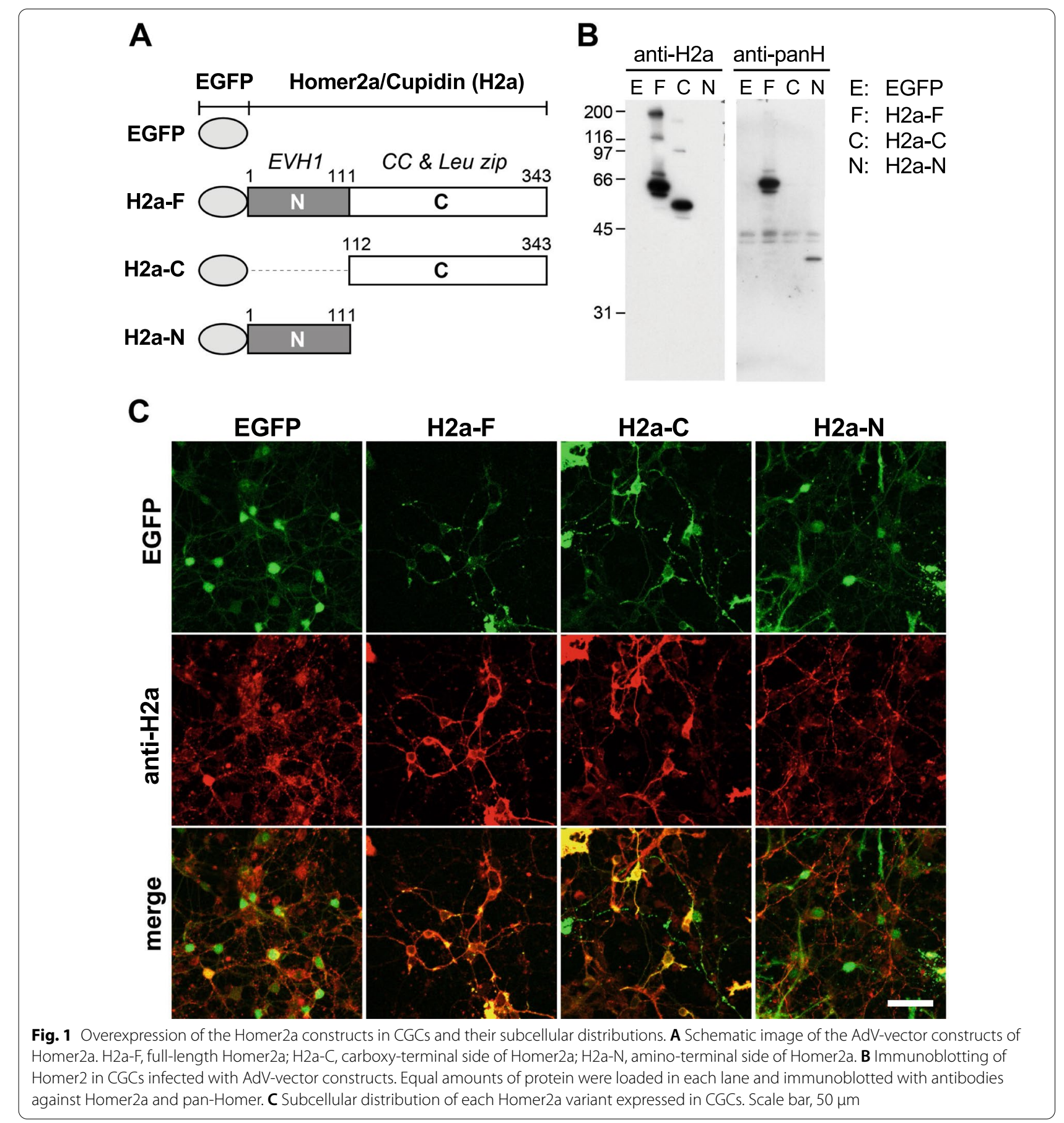

B 
because it lacked the epitope for this antibody (Fig. 1B, left). The anti-panHomer antibody, which binds to the $\mathrm{N}$-terminus of all Homer family isoforms, detected H2a-F and $\mathrm{H} 2 \mathrm{a}-\mathrm{N}$ but not $\mathrm{H} 2 \mathrm{a}-\mathrm{C}$ (Fig. 1B right). These results indicated that the recombinant AdV-Homer2a infection successfully induced the overexpression of Homer2a proteins in CGCs.

Next, we analyzed the subcellular localization of endogenous Homer2a and its overexpressed mutants in CGCs (Fig. 1C). The endogenous Homer2a was observed in cultured CGCs mostly in a punctate pattern at postsynaptic sites as we previously reported $[14,18]$. In CGCs overexpressing EGFP-fused H2a-F, EGFP fluorescence were observed as punctate pattern along dendrites, which is thought to be postsynaptic sites. However, when EGFPfused $\mathrm{H} 2 \mathrm{a}-\mathrm{C}$ and $\mathrm{H} 2 \mathrm{a}-\mathrm{N}$ were overexpressed, EGFP fluorescence were observed mainly in soma and neurites with punctate pattern along dendrites.

\section{Colocalization of Homer2a and NMDAR}

Because Homer2a binds and regulates postsynaptic proteins $[14,26]$, we examined the colocalization of postsynaptic glutamate receptor NR1 and Homer mutants in CGCs (Fig. 2). The immunoreactivity for recombinants of Homer2 appeared to be localized at the area immunoreactive to NR1 with punctate pattern. On the other hand, the punctate immunoreactivity of NR1 was disappeared in H2a-N overexpressed CGCs. These data suggest that Homer2a overexpression alters the localization of NR1, which may affect the physiological phenotype of CGCs.

\section{NMDA currents decrease upon overexpression of the $\mathrm{N}$-terminal domain of Homer2a}

NMDAR is a calcium permeable glutamate receptor, which is related to several critical cellular events such as synaptic plasticity, cellular differentiation, and apoptosis [27]. To examine the effects of Homer2a overexpression on the physiological response of NMDAR, we carried out whole-cell patch-clamp recordings on CGCs (Fig. 3). In naive CGCs, application of $50 \mu \mathrm{M}$ NMDA under voltage clamp at $-60 \mathrm{mV}$ elicited inward currents that were blocked by AP5, an NMDAR antagonist (Fig. 3A). We also recorded these NMDA currents in AdV-infected CGCs (Fig. 3A, B). Compared with EGFP-expressing CGCs, in H2a-F-overexpressing CGCs the amplitude of NMDA currents tended to be increased. However, consistent with the altered localization of NR1, H2a-N-overexpressing CGCs showed a significantly lower NMDA current amplitude (Fig. 3B).

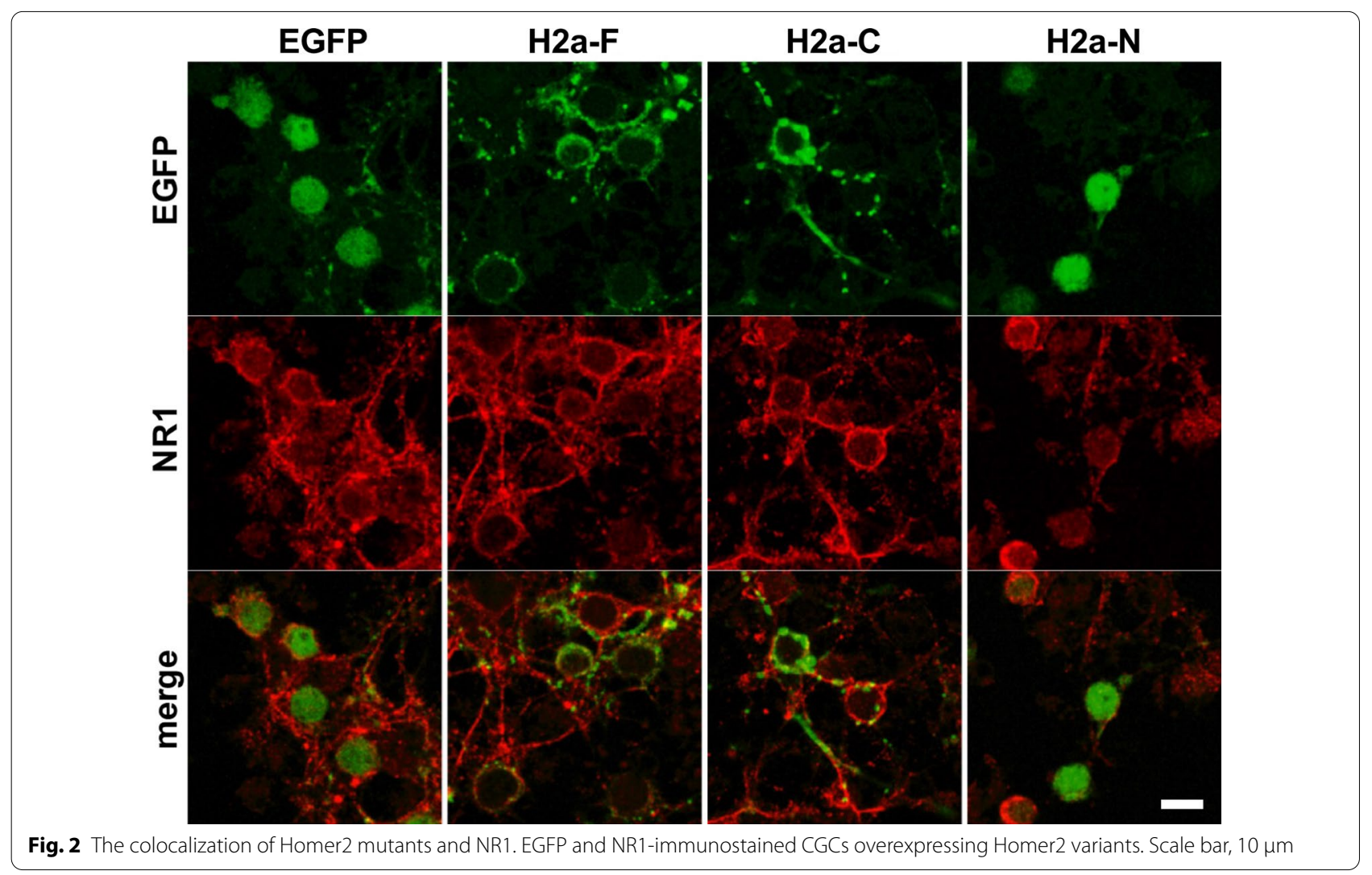




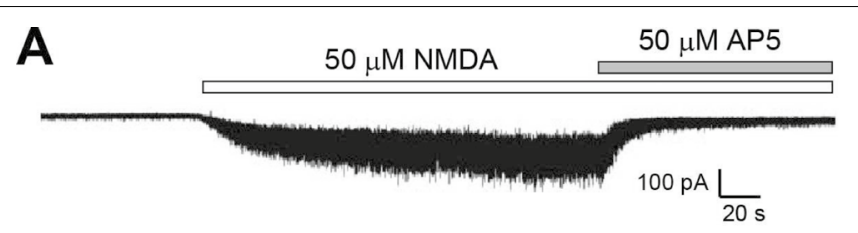

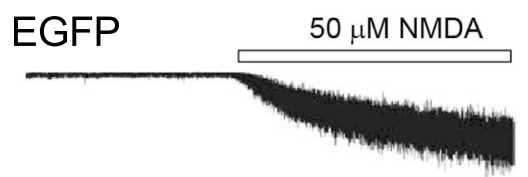

$\mathrm{H} 2 \mathrm{a}-\mathrm{C}$
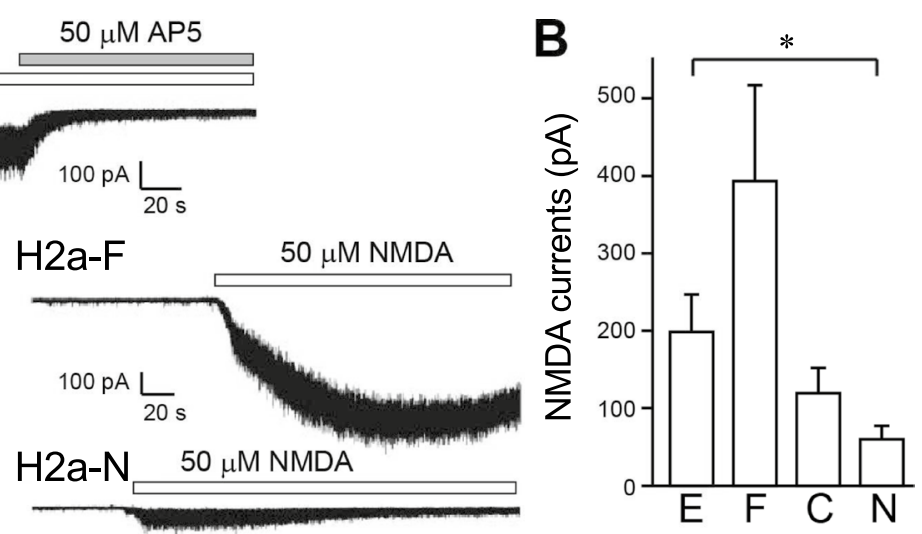

Fig. 3 NMDAR currents were decreased by overexpression of the N-terminal domain of Homer2a. A Top row: representative NMDA-induced inward current trace from control (non-AdV-infected) CGCs. Middle and bottom rows: representative current traces from CGCs infected with EGFP or Homer 2 constructs. Whole cell recordings were performed $48 \mathrm{~h}$ after infection. B Quantification of NMDA currents. Infection with $\mathrm{H} 2 \mathrm{a}-\mathrm{N}$ caused a significant decrease in the NMDA current compared with the EGFP group. E: EGFP, F: H2a-F, C: H2a-C, N: H2a-N. * p<0.05, one-way ANOVA and post hoc Bonferroni test. $n=3$

\section{Overexpression of the Homer2a N-terminal domain suppresses NMDA-mediated cell death of CGCs}

Changes in NMDAR localization and activity are associated with cell apoptosis [17]. Therefore, we examined the cell viability of AdV-infected CGCs after NMDA administration. We treated the cells with different doses of NMDA with or without AP5 and analyzed the NMDA-induced cell death of $\mathrm{H} 2 \mathrm{a}-\mathrm{F},-\mathrm{C}$ or $-\mathrm{N}$-overexpressing CGCs by the MTT assay (Fig. 4). Among these cells, the relative MTT values of $\mathrm{H} 2 \mathrm{a}-\mathrm{N}$-overexpressing CGCs were the highest after treatment with all NMDA doses $(100 \mu \mathrm{M}, 300 \mu \mathrm{M}$, and $1 \mathrm{mM})$, however this difference was diminished by co-application of AP5. These results indicated that $\mathrm{H} 2 \mathrm{a}-\mathrm{N}$-overexpressing $\mathrm{CGCs}$ were more resistant to NMDAR-mediated excitotoxicity than EGFP, $\mathrm{H} 2 \mathrm{a}-\mathrm{F}$, and $\mathrm{H} 2 \mathrm{a}-\mathrm{C}$-overexpressing CGCs.

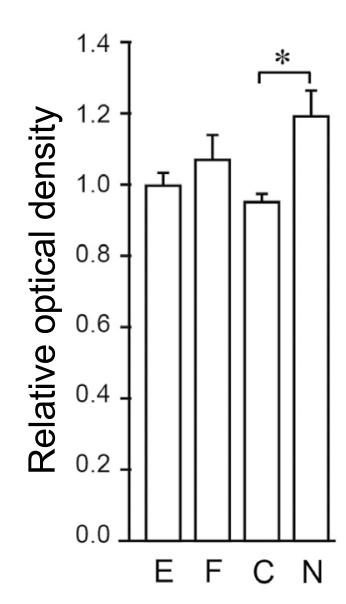

Control
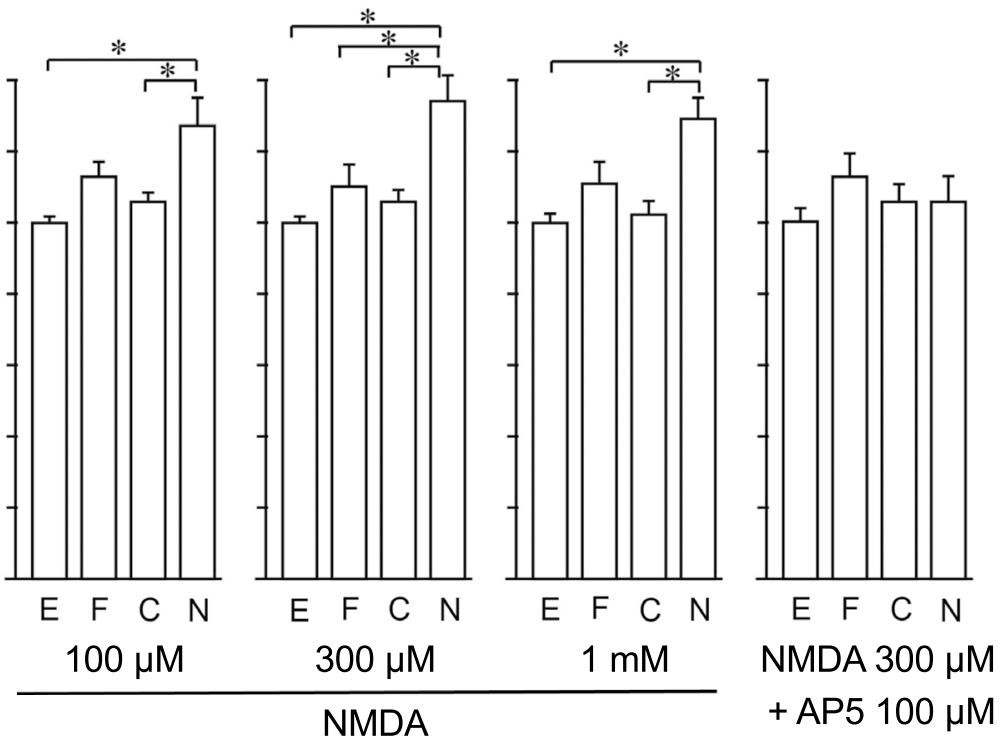

Fig. 4 Overexpression of the Homer2a N-terminal domain suppressed NMDA-induced apoptosis. Normalized optical density of MTT assays of CGCs overexpressing EGFP or Homer2 constructs after the indicated NMDA treatment. NMDA-induced cell death was inhibited in H2a-N-overexpressing CGCs under all doses of NMDA. E: EGFP, F: H2a-F, C: H2a-C, N: H2a-N. * $p<0.05$, one-way ANOVA and post hoc Bonferroni test; $n=3$ 


\section{The newly identified short isoform, Homer2e, is induced by ischemia}

Because overexpression of $\mathrm{H} 2 \mathrm{a}-\mathrm{N}$, a Homer1a-like short Homer2a, exerted resistance to NMDAR-induced apoptosis of CGCs, it is possible that apoptosis-dependent expression of short Homer2 proteins can function as an apoptosis-resistance molecule, just like Homer1a [1113]. To examine whether any of short Homer2 isoforms are expressed in apoptotic CGCs, we performed nested and RT-PCR analysis of Homer 2 mRNA expressed before and after apoptosis induction (Fig. 5). In the cerebellum of mouse ischemic brain, we detected by nested PCR a Homer2-derived band (Fig. 5A). The same nested PCR product was also obtained from cultured CGCs with OGD, which induces apoptosis in CGCs [28]. Sequence analysis identified this product as an alternative splicing variant of Homer2a containing a frame shift that occurred by skipping exon 5 and a part of exon6 (Fig. 5B, C). The open reading frame predicted for this novel product, named Homer2e, is composed of 174 amino acids, including the entire $\mathrm{N}$-terminal target-binding domain, but lacking the C-terminal domain of Homer2a. This frame-shifted C-terminus domain of Homer2e (CCQCEEVGDGAADPAGEQRPADHGTAGVGGQRGAVEAAVLHLQGRE) did not match any protein domains from conserved domain sequence database in NCBI. Thus, this novel isoform is thought to be structurally similar to the short Homer1a, and may act as a dominant negative of long Homer2a.

\section{Discussion}

Our study showed that overexpression of the Homer2a $\mathrm{N}$-terminal domain decreased NR1 localization and the NMDA currents, and had an antiapoptotic function in CGCs. Moreover, we identified a new short Homer2 isoform, Homer2e, which was upregulated in response to apoptotic conditions and ischemic brain injury.

Because of the relationship between Homer proteins and cell apoptosis [29], the representative short form Homer, Homer1a, has been extensively studied as a dominant negative regulator for apoptosis. For example, Homer1a blocked tumor necrosis factor-a/cycloheximide-induced apoptotic cell death via the mitogenactivated protein kinase pathway in PC12 cells [13]. In retinal ganglion cells, retinal ischemia and reperfusion induced Homerla expression, showing neuroprotective effects [12]. Knockdown of Homer1a reduced the cytoprotective effect of Chikusetsu saponin IVa, which controls the reactive oxygen species and intracellular $\mathrm{Ca}^{2+}$ homeostasis in cardiomyocytes [30]. Overexpression of Homer1a inhibited the PI3K/AKT/mTOR signaling pathway, enhanced autophagy and cell viability of rat cortical neurons [31]. Homerla is upregulated in reactive astrocytes and protects astrocytes from apoptosis [11]. Additionally, upregulated Homer1a in astrocytes downregulated astrocytic glutamate release by precluding the mGluR5-mediated intracellular $\mathrm{Ca}^{2+}$ signaling [11]. In contrast, the long Homer 1 isoform, Homer1b and c, have been reported as promoters of neuronal apoptosis via a Bax/Bcl-2-dependent pathway [32]. Furthermore, the other long Homer isoforms, Homer2a, has been shown to be involved in apoptosis of cultured endothelial cells [33].These studies indicate that Homer proteins are associated with several signaling pathways related to apoptosis in neuronal and non-neuronal cells, and especially short Homer proteins may play an important role in protection from apoptotic cell death. In the present study, we addressed the possible role of Homer2e, which is induced via ischemic condition, disassembles postsynaptic Homer-Shank-NMDAR clusters, attenuates excess calcium influx, and prevents apoptosis in CGCs (Fig. 6).

Long Homer proteins have two characteristic structural domains, the N-terminal EVH-1 domain and the Homerspecific C-terminal domain, whereas short Homer proteins lack the C-terminal domain [5]. The EVH-1 domain binds to the proline-rich amino acid sequence, Pro-Pro$\mathrm{X}-\mathrm{X}$-Phe, which is found in many target proteins including the Shank protein family [34]. Shank proteins are scaffold postsynaptic proteins that directly or indirectly bind to several postsynaptic proteins including NMDAR, to tether them to specific postsynaptic sites [35]. The $\mathrm{C}$-terminal domain of Homer consists of a coiled-coil structure followed by two leucine zipper motifs, which form homo- or heteromeric interactions between long Homers [1]. Because short Homers lacking the C-terminal domain cannot interact with other Homer proteins, short Homer proteins are thought to act as dominant negative regulators of long Homer proteins, thereby affecting the distribution of postsynaptic proteins to alter the physiological functions of postsynapses. In fact, overexpression of recombinant Homerla decreased the clusters of PSD95, NR1, and GluR2, a subunit of AMPA type glutamate receptor, and reduced NMDAR and AMPARmediated postsynaptic currents [36]. Additionally, the activity-dependent expression of Homer1a induced rapid de-clustering of Homer1c as well as PSD95 and GluR2 [37]. Although there is difference between Homer1 and 2 in the cellular and regional expression pattern in the brain [15] and phenotypes of knockout mice [38], the short Homer2e may act as a natural dominant negative regulator of the long Homer $2 \mathrm{a} / \mathrm{b}$. In the present study, we did not measure the protein expression level of Homer2e because lack of specific antibody. If Homer2e can act as a dominant negative of long Homer2, protein expression level of Homer2e should be considered. In addition, historical publications reported that short Homer1a protein 
A

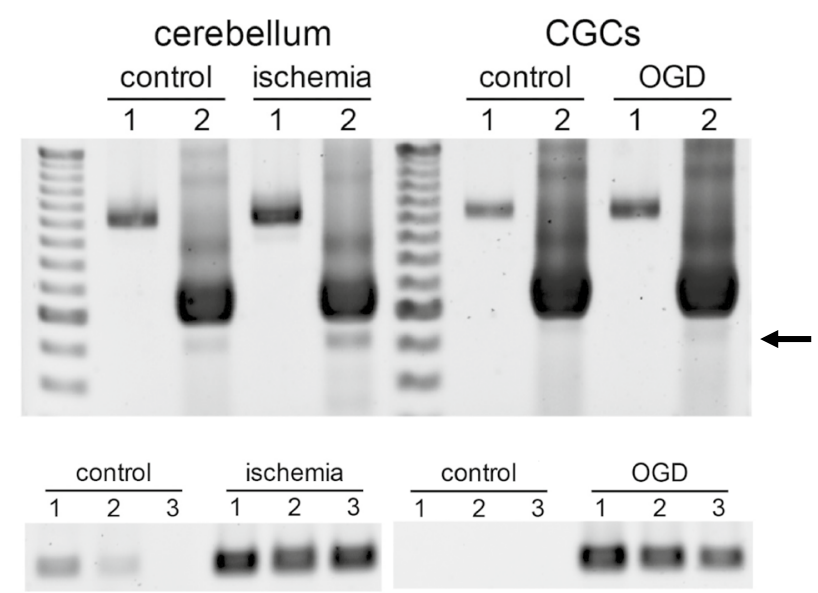

B

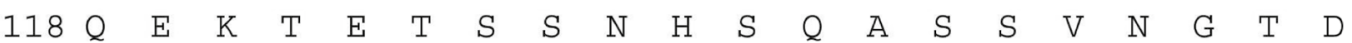
H2a 353 AGGAGAAAACCGAGACCTCCAGCAATCATTCCCAAGCATCCAGCGTCAATGGCACAGACG

H2e 353 AGGAGAAAACCGAGACCTCCAGCAATCATTCCCAA $\ldots \ldots$

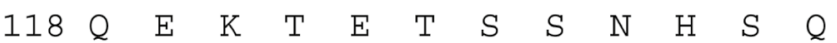

$\begin{array}{lllllllllllllllllllll}138 & \mathrm{D} & \mathrm{E} & \mathrm{K} & \mathrm{A} & \mathrm{S} & \mathrm{H} & \mathrm{A} & \mathrm{S} & \mathrm{P} & \mathrm{A} & \mathrm{D} & \mathrm{T} & \mathrm{H} & \mathrm{L} & \mathrm{K} & \mathrm{S} & \mathrm{E} & \mathrm{N} & \mathrm{D} & \mathrm{K}\end{array}$

H2a 413 ACGAAAAGGCCTCTCACGCGAGCCCAGCCGACACTCACCTCAAGTCTGAGAATGACAAGC

H2e $388 \ldots \ldots \ldots \ldots \ldots \ldots \ldots$

129

$\begin{array}{lllllllllllllllllllll}158 & \mathrm{~L} & \mathrm{~K} & \mathrm{I} & \mathrm{A} & \mathrm{L} & \mathrm{T} & \mathrm{Q} & \mathrm{S} & \mathrm{A} & \mathrm{A} & \mathrm{N} & \mathrm{V} & \mathrm{K} & \mathrm{K} & \mathrm{W} & \mathrm{E} & \mathrm{M} & \mathrm{E} & \mathrm{L} & \mathrm{Q}\end{array}$

H2a 473 TGAAGATCGCGCTGACACAGAGTGCTGCCAATGTGAAGAAGTGGGAGATGGAGCTGCAGA

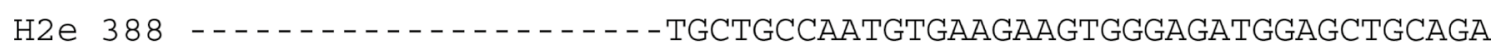

$\begin{array}{lllllllllllllll}129 & C & C & Q & C & E & E & V & G & D & G & A & A & D\end{array}$

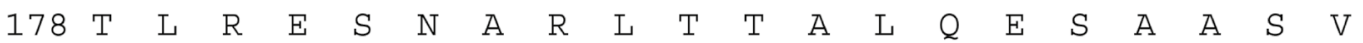

H2a 533 CCCTGCGGGAGAGCAACGCCCGGCTGACCACGGCACTGCAGGAGTCGGCGGCCAGCGTGG

H2e 426 CCCTGCGGGAGAGCAACGCCCGGCTGACCACGGCACTGCAGGAGTCGGCGGCCAGCGTGG

$\begin{array}{llllllllllllllllllllll}142 & \mathrm{P} & \mathrm{A} & \mathrm{G} & \mathrm{E} & \mathrm{Q} & \mathrm{R} & \mathrm{P} & \mathrm{A} & \mathrm{D} & \mathrm{H} & \mathrm{G} & \mathrm{T} & \mathrm{A} & \mathrm{G} & \mathrm{V} & \mathrm{G} & \mathrm{G} & \mathrm{Q} & \mathrm{R} & \mathrm{G}\end{array}$

$\begin{array}{lllllllllllllllllllll}198 & \mathrm{E} & \mathrm{Q} & \mathrm{W} & \mathrm{K} & \mathrm{R} & \mathrm{Q} & \mathrm{F} & \mathrm{S} & \mathrm{I} & \mathrm{C} & \mathrm{R} & \mathrm{D} & \mathrm{E} & \mathrm{N} & \mathrm{D} & \mathrm{R} & \mathrm{L} & \mathrm{R} & \mathrm{S} & \mathrm{K}\end{array}$

H2a 593 AGCAGTGGAAGCGGCAGTTCTCCATCTGCAGGGACGAGAATGACAGGCTCCGCAGCAAGA

H2e 486 AGCAGTGGAAGCGGCAGTTCTCCATCTGCAGGGACGAGAATGACAGGCTCCGCAGCAAGA

$\begin{array}{llllllllllllllll}162 & \mathrm{~A} & \mathrm{~V} & \mathrm{E} & \mathrm{A} & \mathrm{A} & \mathrm{V} & \mathrm{L} & \mathrm{H} & \mathrm{L} & \mathrm{Q} & \mathrm{G} & \mathrm{R} & \mathrm{E} & * & \left(\begin{array}{lll}174 & \mathrm{a} a\end{array}\right)\end{array}$

C

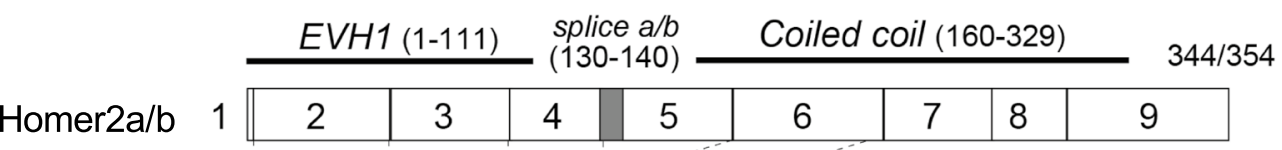

Homer2e 1

\section{\begin{tabular}{l|l|l|l|}
2 & 3 & 4 & $\Delta 6$ \\
\hline
\end{tabular}}

Fig. 5 Identification of a new Homer2 variant, Homer2e, induced by ischemia in mouse cerebellum and by OGD in CGCs. A Upper, nested PCR of mouse cerebellum cDNA performed on the coding region of Homer2a. The first and the second PCR reactions are depicted as 1 and 2. In the second PCR, a small size band just underneath the major band was detected particularly in ischemic and OGD samples (arrow). Lower, RT-PCR detection of Homerze in the cerebellum and CGCs. Homerze increased in both ischemic cerebellum and OGD CGCs. Three individual animals $(n=3)$ and cultures $(n=3)$ were analyzed in each condition. B Comparison of the partial nucleotide and deduced amino acid sequences between Homer2a and Homer2e. C Comparison of exons between Homer2a/b and Homer2e. Exons 5 and 7-9 of Homer2a/b are lacking in Homer2e. Because the nucleotide deficits cause a frameshift, Homer2e encodes a potential protein of 174 amino acids, which lacks the C-terminal of Homer2a/b 

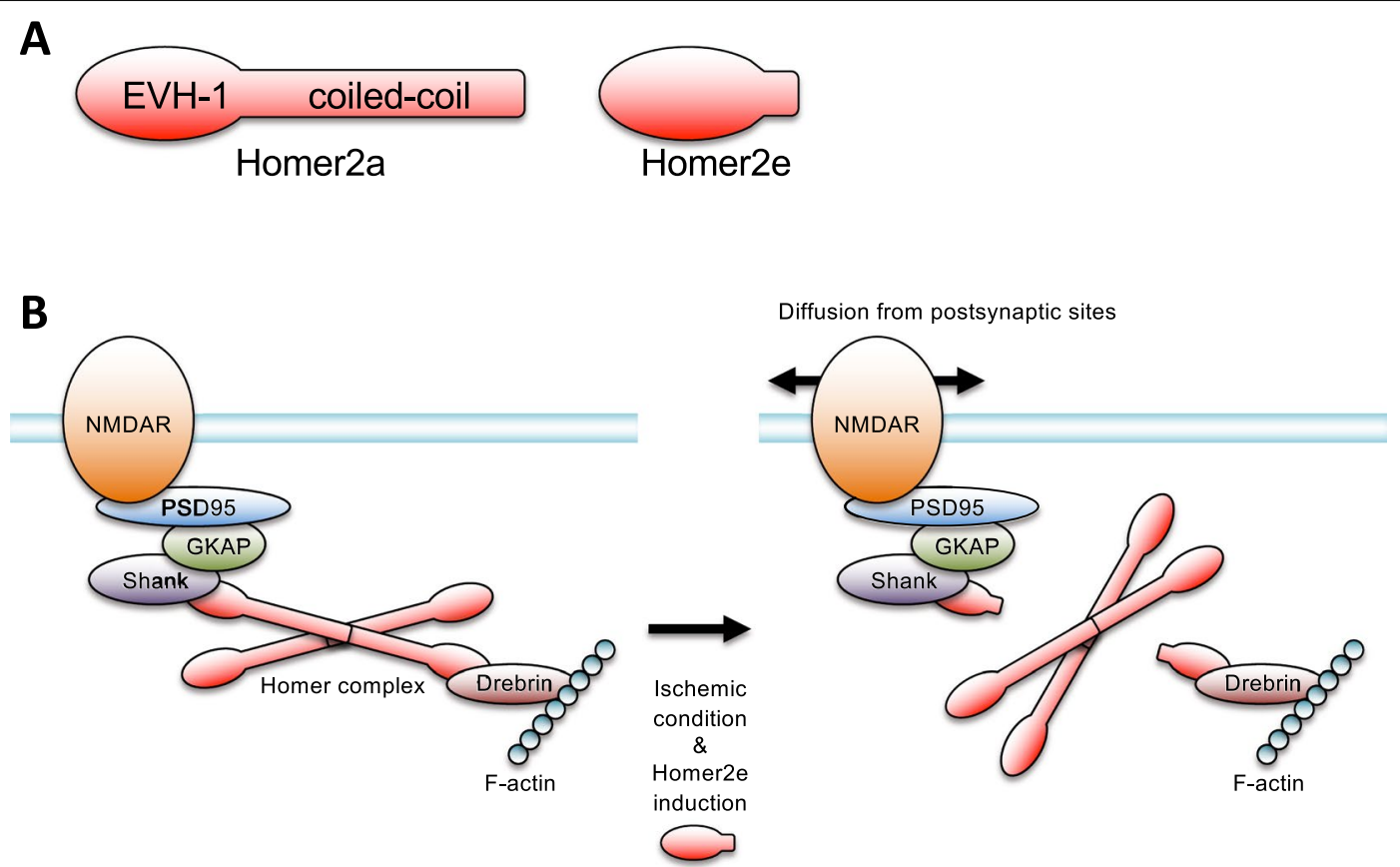

Fig. 6 Schematic diagram of Homer2a/2e and their possible role. A Schematic structure of Homer2a and 2e. Long Homer2a has EVH-1 domain in N-terminal and coiled-coil domain in C-terminal. Homer2e has only EVH-1 domain and lack of coiled-coil domain. B Schematic diagram of the possible role of Homer2a and 2e. Left: Long Homer2a multimerizes using their C-terminus coiled-coil domain and binds to Shank and Drebrin using their N-terminus EVH-1 domain to stabilize NMDAR at the postsynaptic site via GKAP, PSD95 and F-actin complex. Right: Ischemic condition induces Homer2e and it prevents the binding between Homer2a and Shank/Drebrin by takeover their EVH-1 binding sites, which enhances declustering of the protein complex including NMDAR in the postsynaptic site

level is very low compared to the constitutively expressed Homers, even when mRNA induction is quite robust [39]. Therefore, it is possible that the protein expression level of induced Homer2e is also low compared with other constitutively expressed Homer2 isoforms. One of the possible explanations of how low-level expressed protein can act effectively as a dominant negative is their specific localization. Since Homer proteins are existing in postsynaptic site, if induced short Homers are accumulated or locally translated at postsynaptic site, the local concentration of these short Homers can compete preexisting long Homers. Therefore, one of the possible and attractive roles of the short Homer2e may be the candidate protein associated with synaptic tagging as Homer1a [40]. The basal and induced protein expression level of Homerla is known to be very low compared to the constitutively expressed long Homers [39]; however, it can be act as a dominant negative in the specific postsynaptic site as synaptic tag.

In addition to the declustering of postsynaptic proteins targeted to N-terminus domain of long Homer2, the proteins targeted to $\mathrm{C}$-terminus domain of long Homer2 are also to be considered as the regulated proteins by Homer2e. Cdc42 is known as a small GTPase of the Rho family, which modulates cell morphology, migration, endocytosis and cell cycle [41], which binds C-terminus domain of Homer2a [26]. Since EVH-1 domain on Homer2a can bind Ophn-1 (GTPase activating protein) and beta-PIX (guanine nucleotide exchange factor) [26], the disruption of the link between Ophn-1/beta-PIX and Cdc42 may affect actin polymerization and subsequent dendritic spine morphology. However, it remains to be elucidated whether short Homer2e plays a role as a dominant negative regulator of the long Homer2 isoform.

In conclusion, our study showed that Homer2a is involved in the regulation of NMDAR currents and plays a role in NMDAR-mediated cell physiology including apoptosis. The novel short isoform, Homer2e, is induced under apoptotic conditions and possibly acts as a dominant negative regulator of the long form of Homer2, i.e., decreases the NMDAR currents, probably resulting in the repression of NMDAR-elicited excitotoxicity and apoptosis. The harmonization between the long and short Homer isoforms in the developing cerebellum may be crucial for fine physiological regulation of CGCs. 


\section{Abbreviations}

CGCs: Cerebellar granule cells; NMDAR: N-methyl-D-aspartate receptor; NR1: NMDA receptor subtype 1; PSD: Postsynaptic density; mGluR: Metabotropic glutamate receptor; $I_{3} R$ : Inositol 1,4,5-trisphosphate receptor; EVH-1: Enabled/vasodilator-stimulated phosphoprotein homology 1; EGFP: Enhanced green fluorescent protein; OGD: Oxygen-glucose deprivation; AdVs: Adenoviruses; DIV: Days in vitro; ANOVA: Analysis of variance.

\section{Acknowledgements}

We thank Dr. Satoshi Shoji for his experimental assistances and data analysis, and Dr. Fumio Yoshikawa for his fruitful comments. We thank Michal Bell, PhD, from Edanz Group (https://en-author-services.edanz.com/ac) for editing a draft of this manuscript.

\section{Authors' contributions}

TF conceived and designed this project, analyzed/interpreted the results, and wrote/revised the manuscript. YM performed the experiments and analyzed the results. TS, YSa, KH, and YS-Y interpreted the results and revised the manuscript. YSh interpreted the results and wrote/revised the manuscript. All authors read and approved the final manuscript.

\section{Funding}

This study was supported by The Mother and Child Health Foundation, Grantsin-Aid for KAKENHI from the Japan Society for the Promotion of Science and the Ministry of Education, Culture, Sports, Science, and Technology of Japan [19K06900 to T.S.; 17 H03563 to T.F.].

\section{Availability of data and materials}

All data generated or analyzed during this study are included in this published article.

\section{Declarations}

\section{Ethics approval and consent to participate}

All animal care and treatment procedures followed the Japanese Act on the Welfare and Management of Animals and the Guidelines for the Proper Conduct of Animal Experiments issued by the Science Council of Japan. All animal experiments were approved by the Animal Care and Experimentation Committee of RIKEN BSI and were carried out following the approved guidelines.

\section{Consent for publication}

Not applicable.

\section{Competing interest}

The authors declare that they have no conflict of interest.

\section{Author details}

${ }^{1}$ Laboratory for Molecular Neurogenesis, RIKEN Brain Science Institute, Wako, Saitama 351-0198, Japan. ${ }^{2}$ JST-CREST, Kawaguchi, Saitama 332-0012, Japan. ${ }^{3}$ Present Address: Department of Applied Biological Science, Faculty of Science and Technology, Tokyo University of Science, Noda, Chiba 278-8510, Japan. ${ }^{4}$ Present Address: Education and Research Support Center, Gunma University Graduate School of Medicine, Maebashi, Gunma 371-8511, Japan. ${ }^{5}$ Present Address: Laboratory of Proteome Research, Laboratory of Proteomics for Drug Discovery, Center for Drug Design Research, National Institutes of Biomedical Innovation, Health and Nutrition, Ibaraki, Osaka 567-0085, Japan. ${ }^{6}$ Present Address: Department of Anatomy, Keio University School of Medicine, Shinjuku-ku, Tokyo 160-8582, Japan. ${ }^{7}$ Present Address: Department of Developing Human Resources for R\&D Programs, Japan Science and Technology Agency (JST), Chiyoda-ku, Tokyo 102-8666, Japan. ${ }^{8}$ Present Address: Department of Environmental Health, School of Pharmacy, Tokyo University of Pharmacy and Life Sciences, Hachioji, Tokyo 192-0392, Japan.

Received: 21 April 2021 Accepted: 4 June 2021

Published online: 12 June 2021

\section{References}

1. Xiao B, Tu JC, Petralia RS, Yuan JP, Doan A, Breder CD, Ruggiero A, Lanahan AA, Wenthold RJ, Worley PF. Homer regulates the association of group 1 metabotropic glutamate receptors with multivalent complexes of homer-related, synaptic proteins. Neuron. 1998;21:707-16.

2. Sala C, Piech V, Wilson NR, Passafaro M, Liu G, Sheng M. Regulation of dendritic spine morphology and synaptic function by Shank and Homer. Neuron. 2001;31:115-30.

3. Tu JC, Xiao B, Yuan JP, Lanahan AA, Leoffert K, Li M, Linden DJ, Worley PF. Homer binds a novel proline-rich motif and links group 1 metabotropic glutamate receptors with IP3 receptors. Neuron. 1998;21:717-26.

4. Brakeman PR, Lanahan AA, O'Brien R, Roche K, Barnes CA, Huganir RL, Worley PF. Homer: a protein that selectively binds metabotropic glutamate receptors. Nature. 1997;386:284-8.

5. Shiraishi-Yamaguchi Y, Furuichi T. The Homer family proteins. Genome Biol. 2007;8:206.

6. Soloviev MM, Ciruela F, Chan WY, Mcllhinney RA. Molecular characterisation of two structurally distinct groups of human homers, generated by extensive alternative splicing. J Mol Biol. 2000;295:1185-200.

7. Hayashi MK, Ames HM, Hayashi Y. Tetrameric hub structure of postsynaptic scaffolding protein homer. J Neurosci. 2006;26:8492-501.

8. Kato A, Ozawa F, Saitoh Y, Hirai K, Inokuchi K. vesl, a gene encoding VASP/ Ena family related protein, is upregulated during seizure, long-term potentiation and synaptogenesis. FEBS Lett. 1997;412:183-9.

9. Thomas U. Modulation of synaptic signalling complexes by Homer proteins. J Neurochem. 2002;81:407-13.

10. Ehrengruber MU, Kato A, Inokuchi K, Hennou S. Homer/Vesl proteins and their roles in CNS neurons. Mol Neurobiol. 2004;29:213-27.

11. Buscemi L, Ginet V, Lopatar J, Montana V, Pucci L, Spagnuolo P, Zehnder T, Grubisic V, Truttman A, Sala C, Hirt L, Parpura V, Puyal J, Bezzi P. Homer1 scaffold proteins govern $\mathrm{Ca} 2+$ dynamics in normal and reactive astrocytes. Cereb Cortex. 2017;27:2365-84.

12. Fei F, Li J, Rao W, Liu W, Chen X, Su N, Wang Y, Fei Z. Upregulation of Homer1a promoted retinal ganglion cell survival after retinal ischemia and reperfusion via interacting with Erk pathway. Cell Mol Neurobiol. 2015;35:1039-48

13. Luo P, Zhao Y, Li D, Chen T, Li S, Chao X, Liu W, Zhang L, Qu Y, Jiang X, Lu $G$, Poon W, Fei Z. Protective effect of Homer 1a on tumor necrosis factoralpha with cycloheximide-induced apoptosis is mediated by mitogenactivated protein kinase pathways. Apoptosis. 2012;17:975-88.

14. Shiraishi Y, Mizutani A, Bito H, Fujisawa K, Narumiya S, Mikoshiba K, Furuichi T. Cupidin, an isoform of HomerNesl, interacts with the actin cytoskeleton and activated rho family small GTPases and is expressed in developing mouse cerebellar granule cells. J Neurosci. 1999;19:8389-400.

15. Shiraishi Y, Mizutani A, Yuasa S, Mikoshiba K, Furuichi T. Differential expression of Homer family proteins in the developing mouse brain. J Comp Neurol. 2004:473:582-99.

16. Lossi L, Gambino G. Apoptosis of the cerebellar neurons. Histol Histopathol. 2008:23:367-80.

17. Contestabile A. Cerebellar granule cells as a model to study mechanisms of neuronal apoptosis or survival in vivo and in vitro. Cerebellum. 2002;1:41-55

18. Shiraishi Y, Mizutani A, Yuasa S, Mikoshiba K, Furuichi T. Glutamateinduced declustering of post-synaptic adaptor protein Cupidin (Homer 2/ vesl-2) in cultured cerebellar granule cells. J Neurochem. 2003;87:364-76.

19. Sadakata T, Kakegawa W, Shinoda Y, Hosono M, Katoh-Semba R, Sekine Y, Sato Y, Saruta C, Ishizaki Y, Yuzaki M, Kojima M, Furuichi T. Axonal localization of Ca2+-dependent activator protein for secretion 2 is critical for subcellular locality of brain-derived neurotrophic factor and neurotrophin-3 release affecting proper development of postnatal mouse cerebellum. PLOS ONE. 2014;9:e99524.

20. Miyake S, Makimura M, Kanegae Y, Harada S, Sato Y, Takamori K, Tokuda C, Saito I. Efficient generation of recombinant adenoviruses using adenovirus DNA-terminal protein complex and a cosmid bearing the full-length virus genome. Proc Natl Acad Sci USA. 1996;93:1320-4.

21. Kanegae $Y$, Makimura M, Saito IA. simple and efficient method for purification of infectious recombinant adenovirus. Jpn J Med Sci Biol. 1994:47:157-66.

22. Shinoda Y, Ahmed S, Ramachandran B, Bharat V, Brockelt D, Altas B, Dean C. BDNF enhances spontaneous and activity-dependent 
neurotransmitter release at excitatory terminals but not at inhibitory terminals in hippocampal neurons. Front Synaptic Neurosci. 2014;6:27.

23. Taniguchi N, Shinoda Y, Takei N, Nawa H, Ogura A, Tominaga-Yoshino K. Possible involvement of BDNF release in long-lasting synapse formation induced by repetitive PKA activation. Neurosci Lett. 2006:406:38-42.

24. Shinoda Y, Tanaka T, Tominaga-Yoshino K, Ogura A. Persistent synapse loss induced by repetitive LTD in developing rat hippocampal neurons. PLoS ONE. 2010;5:10390.

25. Yan B, He J, Xu H, Zhang Y, Bi X, Thakur S, Gendron A, Kong J, Li XM. Quetiapine attenuates the depressive and anxiolytic-like behavioural changes induced by global cerebral ischemia in mice. Behav Brain Res. 2007;182:36-41.

26. Shiraishi-Yamaguchi Y, Sato Y, Sakai R, Mizutani A, Knopfel T, Mori N, Mikoshiba K, Furuichi T. Interaction of Cupidin/Homer2 with two actin cytoskeletal regulators, Cdc42 small GTPase and Drebrin, in dendritic spines. BMC Neurosci. 2009;10:25.

27. Traynelis SF, Wollmuth LP, McBain CJ, Menniti FS, Vance KM, Ogden KK, Hansen KB, Yuan H, Myers SJ, Dingledine R. Glutamate receptor ion channels: structure, regulation, and function. Pharmacol Rev. 2010;62:405-96.

28. Kalda A, Eriste E, Vassiljev V, Zharkovsky A. Medium transitory oxygenglucose deprivation induced both apoptosis and necrosis in cerebellar granule cells. Neurosci Lett. 1998;240:21-4.

29. Maher P, van Leyen K, Dey PN, Honrath B, Dolga A, Methner A. The role of $\mathrm{Ca}(2+)$ in cell death caused by oxidative glutamate toxicity and ferroptosis. Cell Calcium. 2018;70:47-55.

30. Duan J, Yin Y, Wei G, Cui J, Zhang E, Guan Y, Yan J, Guo C, Zhu Y, Mu F, Weng Y, Wang Y, Wu X, Xi M, Wen A. Chikusetsu saponin IVa confers cardioprotection via SIRT1/ERK1/2 and Homer1a pathway. Sci Rep. 2015;5:18123.

31. Wang Y, Zhao M, Shang L, Zhang Y, Huang C, He Z, Luo M, Wu B, Song P, Wang M, Duan F. Homer1a protects against neuronal injury via PI3K/AKT/ mTOR signaling pathway. Int J Neurosci. 2020;130:621-30.
32. Cui Z, Zhou L, Liu C, Zhu G, Wu X, Yan Y, Xia X, Ben Z, Song Y, Zhou Y, Zhang $\mathrm{H}$, Zhang D. The role of Homer $1 \mathrm{~b} / \mathrm{c}$ in neuronal apoptosis following LPS-induced neuroinflammation. Neurochem Res. 2015;40:204-15.

33. Kim JT, Park SH, Kim SK, Kwon EY, Do MH, Hwang TH. Potential role of Homer-2a on cutaneous vascular anomaly. J Korean Med Sci. 2002;17:636-40.

34. Tu JC, Xiao B, Naisbitt S, Yuan JP, Petralia RS, Brakeman P, Doan A, Aakalu VK, Lanahan AA, Sheng M, Worley PF. Coupling of mGluR/Homer and PSD-95 complexes by the Shank family of postsynaptic density proteins. Neuron. 1999;23:583-92.

35. Sheng M, Kim E. The Shank family of scaffold proteins. J Cell Sci. 2000;113(Pt 11):1851-6.

36. Sala C, Futai K, Yamamoto K, Worley PF, Hayashi Y, Sheng M. Inhibition of dendritic spine morphogenesis and synaptic transmission by activityinducible protein Homer1a. J Neurosci. 2003;23:6327-37.

37. Inoue $\mathrm{Y}, \mathrm{Udo} \mathrm{H}$, Inokuchi K, Sugiyama H. Homerla regulates the activityinduced remodeling of synaptic structures in cultured hippocampal neurons. Neuroscience. 2007;150:841-52.

38. Szumlinski KK, Kalivas PW, Worley PF. Homer proteins: implications for neuropsychiatric disorders. Curr Opin Neurobiol. 2006;16:251-7.

39. Kato A, Ozawa F, Saitoh Y, Fukazawa Y, Sugiyama H, Inokuchi K. Novel members of the Vesl/Homer family of PDZ proteins that bind metabotropic glutamate receptors. J Biol Chem. 1998;273:23969-75.

40. Okada D, Ozawa F, Inokuchi K. Input-specific spine entry of soma-derived Vesl-1S protein conforms to synaptic tagging. Science. 2009;324:904-9.

41. Qadir MI, Parveen A, Ali M. Cdc42: role in cancer management. Chem Biol Drug Des. 2015;86:432-9.

\section{Publisher's Note}

Springer Nature remains neutral with regard to jurisdictional claims in published maps and institutional affiliations.
Ready to submit your research? Choose BMC and benefit from:

- fast, convenient online submission

- thorough peer review by experienced researchers in your field

- rapid publication on acceptance

- support for research data, including large and complex data types

- gold Open Access which fosters wider collaboration and increased citations

- maximum visibility for your research: over 100M website views per year

At BMC, research is always in progress.

Learn more biomedcentral.com/submissions 